\title{
Influence of depreciation calculation of fixed assets on the optimization of income tax
}

\author{
Irina Zaslavskaya ${ }^{1, *}$ \\ ${ }^{1}$ Moscow State University of Civil Engineering, Yaroslavskoye shosse, 26, Moscow, 129337, Russia
}

\begin{abstract}
The article explores the possibility of applying various approaches to the depreciation calculation in tax accounting, it takes into the account characteristics of depreciable assets, the establishment of various useful lives and methods for calculating depreciation. The article analyses the possibility of using an alternative choice of calculating depreciation in order to reduce the tax burden on the enterprise in terms of income tax. The attention is focused on the application of tax benefits established by the Tax Code. It can be used in calculating depreciation of fixed assets. The author deals with the main differences between the depreciation calculation of charges of fixed assets in accounting and tax accounting, she formulates the problems arising due to different approaches to the estimation of initial cost and depreciation calculation.
\end{abstract}

\section{Introduction}

Accounting for depreciation of fixed assets is one of the most difficult issues in modern Russian accounting and tax accounting. The difference in approaches to the recognition of fixed assets, in the formation of the initial cost, in the methods of calculating depreciation leads to disagreements in accounting while calculating the taxable profits.

Accounting and tax accounting in the Russian Federation is regulated by laws, compliance of which is the responsibility of each organization. With regard to the accounting of fixed assets, including accrual of depreciation, the main legislative document in accounting is Russian Accounting Regulations 6/01 "Accounting for fixed assets." This document prescribes the requirements for accounting for fixed assets, but at the same time offers an alternative approach while choosing the method of calculating depreciation, establishing a cost criterion for classifying assets as fixed assets, etc. Based on RAR 6/01, an organization can choose its own accounting option and consolidate it into accounting policy.

In the tax accounting for reflection of amortization expenses it is necessary to observe the rules established by the Tax Code and the correct application of tax terms. But, despite the strict requirements of tax legislation for the calculation of income tax, the accountant is given some freedom of choice in determining the estimated useful life, the method of calculating depreciation, usage of tax benefits, which allows you to reduce the tax burden on the organization throughout the management of depreciation.

\footnotetext{
*Corresponding author: ivz-mgsu@mail.ru
} 


\section{Materials and Methods}

The process of determining the monthly amortization expenses in tax accounting starts with the recognition of the property as amortizing one, in other words "with an established useful life of more than 12 months and an initial value of more than 100,000 rubles" (art. 256 of the Tax Code of the Russian Federation) [1]. The cost criterion is set for all taxpayers of income tax and, unlike accounting, is not subject to adjustment. To calculate the initial value of the acquired depreciable property, the accountant must include in it the amount of expenses for the acquisition, construction, manufacturing, delivery and bringing to the state in which it is suitable for use, with the exception of value added tax and excises (art. 255 of the Tax Code of the Russian Federation) [2]. If the amount of all the mentioned expenses exceeds 100,000 rubles, then this object is supposed to be depreciable property. However, accounting in RAR 6/01 "Accounting for fixed assets" says that if an object consists of several parts that have different established useful lives, then each part can be registered as an independent inventory object. [3]. In the Tax Code the concept of an "inventory object" is not established, but if as a result of calculations, the cost of such facilities is less than the established criterion, then depreciation on them will not be accrued in tax accounting. In order to correctly register individual components of fixed assets, it is necessary to follow exactly the formulations prescribed in the Tax Code. Therefore, when registering a fixed asset, it is necessary to take into account the possibility of its application as a means of labor in the production and sale process, the composition and functional purpose of its parts, the possibility of disaggregating of the property, the useful life of its components. If all devices or components are able to perform their functions only as part of the complex, then for taxation purposes they must be considered as a single unit of depreciable property.

The registration of individual components of fixed assets in some cases can significantly reduce the profit tax due to simultaneous depreciation of property value into the composition of expenses. But since there is no precise description of such a procedure in the Tax Code, this approach carries certain tax risks associated with the erroneous interpretation of individual components as an independent fixed asset.

The next most important factor affecting the amount of depreciation is the establishment of useful life. Assignment of a fixed asset to one of the ten depreciation groups established by the Tax Code obliges the accounting specialist to select a specific number of months from the established minimum and maximum limits.

At first glance, the choice of the established useful life is based on the physical characteristics of the facility and requires knowledge of the specifics of the organization's activities, but when approaching the management of depreciation as a method of reducing the tax burden, it is also necessary to analyze the tax burden and preventive calculation of alternative depreciation options for different useful lives.

The choice of fewer months increases the amount of monthly depreciation and reduces the profit of the organization, and, consequently, a longer useful life increases the tax on profits. Thus, the subjective accounting choice of the useful life period influences the increase or decrease in monthly expenses included in the taxable base for income tax.

In addition to the useful life, the depreciation method is influenced by the accrual method used, the choice of which is the prerogative of the accountant. The number of methods for calculating depreciation in tax accounting is limited by two options established by the Tax Code: the linear method and the nonlinear one.

Depending on the chosen method of depreciation accrual, the amount of monthly expenses will be different. In practice, the accountant usually uses the linear method of calculating depreciation, which implies a monthly write-off of depreciation charges throughout the useful life. 
It happens because of a number of reasons, among which are the following:

- the same algorithm for depreciation calculation, both in accounting and in tax accounting, which greatly facilitates the accounting process, allowing to avoid the calculation of temporary differences in the calculation of income tax;

- applicability to all depreciation groups of fixed assets (in tax accounting, only linear way of depreciation can be applied to fixed assets related to the 8-10th amortization groups);

- simplicity of calculation both manually and while using any automatic accounting program.

Within a non-linear method, depreciation is not accrued for each object of depreciable property, but for the amortization group as a whole. The procedure for calculating the amount of depreciation when applying the non-linear accrual method is defined in Art. 259.2 of the Tax Code [4].

Non-linear method allows you to write off more costs in the first months of operation. The advantage of this method is especially clear in the presence of a large number of fixed assets belonging to one group, which is important for large companies. However, buildings, constructions, transfer devices, intangible assets are included in the 8-10th depreciation groups, so only the linear method can be applied in such a case.

The tax legislation grants organizations the right to use certain methods when calculating depreciation charges, which, with proper application, allows more flexible management of the tax burden through depreciation.

When calculating depreciation, a taxpayer can use tax benefits, which include the application of multiplying (decreasing) coefficients to the depreciation rate and the right to perform a lump-sum writing-off of the part of the fixed asset.

The right to apply multiplying (decreasing) coefficients to the depreciation rate prescribed in Article 259.3 of the Tax Code leads to a significant increase in depreciation charges, together with a reduction in the established useful life, which is economically justified for certain categories of machinery and equipment. The application of this benefit is limited by several conditions, mainly by certain types of fixed assets (for example, the ones used for work in an aggressive environment, the ones being the subject of a financial leasing contract, the ones used in activities related to the extraction of hydrocarbon raw materials having high energy efficiency and some others) [5]. For the different types of fixed assets, the maximum value of the coefficients is 2 or 3 . Another limitation concerns organizations applying the non-linear method of calculating depreciation. In this case, the special coefficient is not applied to fixed assets related to the first or third amortization groups [6]. This tax relief is applied only in tax accounting. Therefore, there appears a temporary difference, regulated by RAR 18/02 "Calculation of income tax". However, from the economic point of view, the application of this tax relief is very effective, since the profit tax is significantly reduced, and the accounting profit will be greater than the tax profit, which is positively reflected in the financial statements.

Another way to reduce the tax burden throughout the management of depreciation is the use of the taxpayer's right to apply the bonus depreciation granted by part 9, art. 258 of the Tax Code. It states that it is possible to perform a lump-sum write-off of the part of the value of a fixed asset straightly to expenses, which can be up to 10 or $30 \%$ at once [7]. The amount of write-off depends on the amortization group of fixed assets: still no more than 30 percent - within the fixed assets related to the 3rd-7th depreciation groups, and no more than 10 percent within the rest groups of fixed assets.

The decrease in the profit tax obtained by using the amortization depreciation is possible only during the reporting period when the fixed asset is registered. During subsequent periods the temporary difference between accounting and tax accounting will lead to an increase in tax, but in a much smaller amount, as it will be distributed over the 
life of the established useful life. Similar to the previous tax relief, this right is applied only in tax accounting and does not affect the accounting profit [8].

In case when the fixed asset is consumed earlier than in five years after it was put into operation by a person who is interdependent with the taxpayer, the amortization depreciation should be "restored", i.e. included in the composition of non-operating income.

\section{Results}

Reducing costs when calculating income tax is an important task of tax optimization. With respect to such type of expense as depreciation, there are various options for calculating depreciation charges. To reduce the tax burden, it is necessary to take into account various factors and use the benefits prescribed in the Tax Code. Table 1 represents options for calculating depreciation charges of fixed assets of commercial organizations that can be used to reduce income tax.

Table 1. Methods of controlling depreciation of fixed assets of commercial organizations in tax accounting.

\begin{tabular}{|c|c|c|c|c|}
\hline No & $\begin{array}{l}\text { Factors } \\
\text { affecting the } \\
\text { amount of } \\
\text { depreciation }\end{array}$ & $\begin{array}{l}\text { Optimization } \\
\text { options }\end{array}$ & Advantages & Disadvantages \\
\hline 1 & $\begin{array}{l}\text { Forming the } \\
\text { initial cost of } \\
\text { the fixed asset }\end{array}$ & $\begin{array}{l}\text { Registration of } \\
\text { individual } \\
\text { inventory } \\
\text { objects worth } \\
\text { than }<100,000 \\
\text { rubles }\end{array}$ & Lump-sum write-off & $\begin{array}{l}\text { Lack of a unified approach to } \\
\text { the recognition of parts of } \\
\text { property as separate objects }\end{array}$ \\
\hline 2 & $\begin{array}{l}\text { Determining } \\
\text { the } \\
\text { established } \\
\text { useful life }\end{array}$ & $\begin{array}{l}\text { Choice of fewer } \\
\text { months from the } \\
\text { time periods of } \\
\text { the depreciation } \\
\text { group }\end{array}$ & $\begin{array}{l}\text { Increased amount of } \\
\text { monthly depreciation } \\
\text { and reduced profits }\end{array}$ & $\begin{array}{l}\text { May not coincide with the wear } \\
\text { and tear in the technical } \\
\text { documentation. Necessary to } \\
\text { proactively calculate the } \\
\text { alternative options for } \\
\text { calculating depreciation for } \\
\text { various useful lives. }\end{array}$ \\
\hline \multirow[t]{2}{*}{3} & $\begin{array}{l}\text { Depreciation } \\
\text { method }\end{array}$ & Linear & $\begin{array}{l}\text { Same algorithm for } \\
\text { calculating depreciation, } \\
\text { both in accounting and } \\
\text { tax accounting, } \\
\text { applicability to all } \\
\text { depreciation groups of } \\
\text { fixed assets, simplicity } \\
\text { of calculation }\end{array}$ & $\begin{array}{l}\text { Uniform accrual of depreciation } \\
\text { does not take into account the } \\
\text { specifics of the use of fixed } \\
\text { assets }\end{array}$ \\
\hline & & Non-linear & $\begin{array}{l}\text { Allows you to write off } \\
\text { more expenses during } \\
\text { the first months of } \\
\text { consumption }\end{array}$ & $\begin{array}{l}\text { Can only apply the linear } \\
\text { method only to the basic } \\
\text { facilities related to the } 8-10 \text { th } \\
\text { amortization groups, not used in } \\
\text { accounting }\end{array}$ \\
\hline 4 & $\begin{array}{l}\text { Right to apply } \\
\text { multiplying } \\
\text { (decreasing) } \\
\text { coefficients to } \\
\text { the depre- } \\
\text { ciation rate } \\
\end{array}$ & $\begin{array}{l}\text { Use of } \\
\text { multiplying } \\
\text { (decreasing) } \\
\text { coefficients }\end{array}$ & $\begin{array}{l}\text { Depreciation charges } \\
\text { significantly increase, } \\
\text { while the established } \\
\text { useful life decreases }\end{array}$ & $\begin{array}{l}\text { Limited with specific types of } \\
\text { fixed assets. Maximum } \\
\text { coefficients is } 2 \text { or } 3 \text {. }\end{array}$ \\
\hline 5 & The rights of & Immediate & Reduction of income & In subsequent periods a \\
\hline
\end{tabular}




\begin{tabular}{|l|l|l|l|}
\hline $\begin{array}{l}\text { the taxpayer } \\
\text { to apply the } \\
\text { amortization } \\
\text { depreciation }\end{array}$ & $\begin{array}{l}\text { lump-sum } \\
\text { write-off to } \\
\text { expenses of the } \\
\text { part of the value } \\
\text { of a fixed asset } \\
\text { (up to } 10 \text { or up } \\
\text { to } 30 \%)\end{array}$ & $\begin{array}{l}\text { tax during the period of } \\
\text { commissioning of a } \\
\text { fixed asset }\end{array}$ & $\begin{array}{l}\text { temporary difference will lead } \\
\text { to an increase in the tax within } \\
\text { the write-off of the basic means } \\
\text { earlier than in five years from } \\
\text { the moment of its introduction } \\
\text { into consumption to the person } \\
\text { who is interdependent with the } \\
\text { tax payer, the amortization } \\
\text { benefit needs to be restored. }\end{array}$ \\
\hline
\end{tabular}

The considered ways of managing depreciation lead to the appearance of a difference between accounting and tax accounting, which complicates their application. However, almost all modern accounting software programs calculate this difference automatically and make it possible to reduce the complexity of applying these methods, which can be used as methods to reduce the tax burden.

\section{Conclusion}

The difference in approaches to the calculation of depreciation charges in accounting and tax accounting leads to the desire of the accountant to use the same methods, not taking into account the possibility of reducing the profit tax. Recently, this trend is increasing, due to significant changes in the accounting of fixed assets, which are aimed at convergence of Russian accounting and IFRS. The expected new Accounting Regulations "Fixed Assets", the project of which is actively discussed by accountants and economists, will increase the difference between accounting and tax accounting for depreciable assets. Its application by accountants implies a more subjective approach in order to choose the established useful life, accrual of depreciation and other aspects of fixed assets, while within the tax accounting it is necessary to be guided by the provisions of the Tax Code.

For the successful application of a tax relief while calculating depreciation, a highly qualified approach is required on the part of economists, both in the field of accounting and tax accounting, which allows managing the tax burden in the enterprise.

\section{References}

1. V. Kankhva, IOP Conference Series: Earth and Environmental Science, 90 (2017)

2. E. Nezhnikova, V. Kankhva, Izvestiya Vysshikh Uchebnykh Zavedenii, Seriya Teknologiya Tekstil'noi Promyshlennosti, 2(368) (2017)

3. B. Semaan, J. Hemsley, ISCRAM 2015 Conference Proceedings - 12th International Conference on Information Systems for Crisis Response and Management, 321-328 (2015)

4. I. Ptuhina, T. Spiridonova, T. Musorina, Applied Mechanics and Materials 725-726, 153-159 (2015)

5. O. Papelniuk, MATEC Web of Conferences 106, 08044 (2017)

6. L.I. Kulikova, Mezhdunarodnyy bukhgalterskiy uchet 37, 2-15 (2015)

7. E. Petrov, Prakticheskiy bukhgalterskiy uchet, 8 (2013)

8. V. Vilken, O. Kalinina, A. Dubgorn, E3S Web of Conferences 33, 03012 (2018), doi:10.1051/e3sconf/20183303012 